\title{
Article
}

\section{Feasibility of a Broad Test Battery to Assess Physical Functioning Limitations of People Experiencing Homelessness}

\author{
Julie Broderick ${ }^{1, * \mathbb{C}}$, Sinead Kiernan ${ }^{1,2}$, Niamh Murphy ${ }^{2}$, Joanne Dowds ${ }^{2}$ and Cliona Ní Cheallaigh ${ }^{3,4}(\mathbb{D}$ \\ 1 Discipline of Physiotherapy, School of Medicine, Trinity College Dublin, University of Dublin, \\ D08 W9RT Dublin, Ireland; sikierna@tcd.ie \\ 2 Department of Physiotherapy, St. James's Hospital, D08 X4RX Dublin, Ireland; nimurphy@stjames.ie (N.M.); \\ jdowds@stjames.ie (J.D.) \\ 3 Department of Clinical Medicine, School of Medicine, Trinity Translational Medicine Institute, Trinity College \\ Dublin, D08 W9RT Dublin, Ireland; nicheacm@tcd.ie \\ 4 Department of Infectious Diseases, St. James's Hospital, Trinity College Dublin, D08 X4RX Dublin, Ireland \\ * Correspondence: julie.broderick@tcd.ie
}

Citation: Broderick, J.; Kiernan, S.; Murphy, N.; Dowds, J.; Ní Cheallaigh, C. Feasibility of a Broad Test Battery to Assess Physical Functioning Limitations of People Experiencing Homelessness. Int. J. Environ. Res. Public Health 2021, 18, 1035. https:// doi.org/10.3390/ijerph18031035

Academic Editors: Kate Frazer and Thilo Kroll

Received: 8 December 2020

Accepted: 19 January 2021

Published: 25 January 202

Publisher's Note: MDPI stays neutral with regard to jurisdictional claims in published maps and institutional affiliations.

Copyright: (c) 2021 by the authors. Licensee MDPI, Basel, Switzerland. This article is an open access article distributed under the terms and conditions of the Creative Commons Attribution (CC BY) license (https:// creativecommons.org/licenses/by/ $4.0 /)$

\begin{abstract}
Background: People who are homeless experience poor health. Reflective of overall health and factors such as acquired injuries, physical ability or functioning is often low among people who are homeless, but there is a lack of consistency of measures used to evaluate this construct. The aim of this study was to evaluate the feasibility of a broad test battery to evaluate limitations in physical functioning among people who are homeless. Methods: This cross-sectional, observational study occurred in a hospital in Dublin, Ireland. We evaluated lower extremity physical function (Short Physical Performance Battery), falls risk (timed up and go), functional capacity (six-minute walk test), stair-climbing ability (stair climb test), frailty (Clinical Frailty Scale), grip strength (handgrip dynamometer) and muscular mass (calf circumference measurement) in a population of people experiencing homelessness admitted for acute medical care. The test completion rate was evaluated for feasibility. Results: The completion rate varied: 65\% (Short Physical Performance Battery), 55.4\% (timed up and go), 38\% (six-minute walk test), 31\% (stair climb test), 97\% (Clinical Frailty Scale), 75\% (handgrip dynamometer), 74\% (calf circumference measurement)). Collectively, the most common reasons for test non-participation were pain $(24.1 \%, n=40)$, not feeling well or able enough $(20.1 \%$, $n=33)$, and declined $(11 \%, n=18)$. Conclusion: The feasibility of the test battery was mixed as test participation rates varied from $31 \%$ to $97 \%$. Physical functioning tests need to be carefully chosen for people who are homeless as many standard tests are unsuitable due to pain and poor physical ability.
\end{abstract}

Keywords: homeless; physical function; frailty; strength; mobility

\section{Introduction}

Homelessness is a significant societal and global problem. A person experiencing homelessness is someone without stable housing who may live on the streets, in a shelter, in temporary accommodation, or in some other unstable or non-permanent situation [1]. It is estimated that there are 307,000 people experiencing homelessness in the U.K. [2], 550,000 in the U.S. [3], and 235,000 in Canada [4] at any one point. Homelessness has increased rapidly in Ireland since 2015 [5].

Homelessness profoundly affects health [2], and the mortality rate for homeless adults is almost four times higher than in the general population [6]. Recent data from the U.K. report a mean age of death among people who were homeless as 45 years for men and 43 years for women, in comparison with 76 and 81 years, respectively, in the general population [7]. People experiencing homelessness suffer a high burden of ill health and frequently have multiple chronic medical conditions $[8,9]$ as well as mental illness and addiction issues [8]. Common chronic diseases such as chronic obstructive pulmonary disease, asthma, epilepsy, heart disease, and stroke are considerably more prevalent among 
people experiencing homelessness compared to housed individuals [10]. It has been reported that people who are homeless are 60 times more likely to present for unscheduled health care in the emergency department [11] and there is a higher rate of acute medical admissions [12]. Doran et al. showed that $70.3 \%$ of all hospitalisations of homeless people result in either an emergency department visit or readmission within 1 month of discharge, with the majority of hospital readmissions occurring within the first 2 weeks after hospital discharge [13].

People who are homeless and admitted for acute inpatient care may represent an especially vulnerable group with distinct care needs due to the complexity of their medical and social problems [14]. It is therefore recommended that clinicians screen this population for physical deficits so appropriate rehabilitation services can be initiated [15]. Due to the earlier onset of geriatric conditions [16] such as falls, poor balance, frailty, and poor mobility, outcomes commonly used to assess people who are homeless are often extrapolated from the geriatric setting [15], but with a much lower mean age [15], the usefulness of these measures is not fully known.

Identification and application of a suitable test battery may indicate a person's ability to perform everyday tasks, their ability to live independently $[8,16]$ and may help identify at risk individuals who need input that is more intensive. This would also target resource use and appropriate discharge planning [16] as well as providing insight into early signs of disability, poor health, and increased death risk [16,17].

The objectives of this study were to assess the feasibility of a comprehensive test battery to assess physical functioning limitations in adults experiencing homelessness.

\section{Materials and Methods}

This single-centre observational cross-sectional study occurred in St. James's Hospital, which is a large university teaching hospital serving adults resident in the south inner city in Dublin, Ireland. It is estimated that approximately 1000 people are sleeping rough or in emergency accommodation within the catchment area of St. James's Hospital [12]. The institutional review board of Tallaght University Hospital/St. James's Hospital approved this study. All participants provided full written informed consent.

\subsection{Test Battery}

A team of expert physiotherapy and medical clinicians/academics devised the test battery by consensus. Considerations were to include tests that: (i) evaluated constructs of impairments, physical functioning and performance, (ii) were not burdensome in terms of time, (iii) required minimal resources in terms of cost and equipment, (iv) could be easy applied to the clinical setting, (v) would be applicable across a spectrum of functional levels, and (vi) displayed sound psychometric properties. The test battery chosen is summarised in Table 1. 
Table 1. Summary of test battery.

\begin{tabular}{|c|c|c|c|c|c|c|}
\hline Test & Construct Measured & $\begin{array}{l}\text { Performance-Based } \\
\text { Measure/Assessed by } \\
\text { Tester }\end{array}$ & Test Description & $\begin{array}{l}\text { Scoring/Unit of } \\
\text { Measurement }\end{array}$ & Interpretation & Reference/Comparative Values \\
\hline $\begin{array}{l}\text { Short Physical } \\
\text { Performance Battery } \\
\text { (SPPB) [18] }\end{array}$ & $\begin{array}{l}\text { Lower extremity } \\
\text { physical function }\end{array}$ & $\begin{array}{l}\text { Performance-based } \\
\text { measure }\end{array}$ & $\begin{array}{l}\text { Consists of } 3 \text { tasks: (i) a balance task, } \\
\text { (ii) } 5 \text { timed chair stands, (iii) a short } \\
\text { timed walk }\end{array}$ & $0-12$ & $\begin{array}{l}\text { Higher scores indicated } \\
\text { better performance }\end{array}$ & $\begin{array}{l}<10 \text { : indicates one or more mobility } \\
\text { limitations [19] }\end{array}$ \\
\hline $\begin{array}{l}\text { Timed Up and Go } \\
\text { (TUG) [20] }\end{array}$ & Falls risk [21] & $\begin{array}{l}\text { Performance-based } \\
\text { measure }\end{array}$ & $\begin{array}{l}\text { Measures the time it takes a person to } \\
\text { stand up from an armchair, walk three } \\
\text { metres and turn back to return to the } \\
\text { chair }\end{array}$ & Timed test (s) & $\begin{array}{l}\text { Higher scores indicate } \\
\text { worse performance }\end{array}$ & $\begin{array}{l}>20 \mathrm{~s} \text { indicates low mobility [22] } \\
>14 \mathrm{~s} \text { indicates high falls risk [23] }\end{array}$ \\
\hline $\begin{array}{l}\text { Six-Minute Walk Test } \\
\text { (6MWT) }\end{array}$ & Functional capacity & $\begin{array}{l}\text { Performance-based } \\
\text { measure }\end{array}$ & $\begin{array}{l}\text { Measures the distance covered up and } \\
\text { down a } 30 \mathrm{~m} \text { course, over a six-minute } \\
\text { period [24] }\end{array}$ & $\begin{array}{l}\text { Distance covered } \\
(\mathrm{m})\end{array}$ & $\begin{array}{l}\text { Higher scores indicate } \\
\text { better performance }\end{array}$ & $\begin{array}{l}\text { Mean (SD) 6MWT distance in healthy } \\
\text { subjects aged } 55-75 \text { years reported as } \\
659(62) \mathrm{m} \text {, with a range } 484-820 \mathrm{~m} \\
{[25]}\end{array}$ \\
\hline $\begin{array}{l}\text { Stair Climb Test (SCT) } \\
\text { [26] }\end{array}$ & Stair climb ability & $\begin{array}{l}\text { Performance-based } \\
\text { measure }\end{array}$ & $\begin{array}{l}\text { Time taken for participants to ascent } \\
\text { and descent stairs with } 11 \text { steps [27] }\end{array}$ & $\begin{array}{l}\text { Time (seconds per } \\
\text { step) }\end{array}$ & $\begin{array}{l}\text { Low score indicates better } \\
\text { performance }\end{array}$ & $\begin{array}{l}\text { A sample of } 106 \text { elderly people with } \\
\text { symptomatic hip or knee osteoarthritis } \\
\text { completed the 11-step SCT with a time } \\
\text { of } 1.14 \text { s per step [26] }\end{array}$ \\
\hline $\begin{array}{l}\text { Clinical Frailty Scale } \\
\text { (CFS) [28] }\end{array}$ & Frailty & Assessed by tester & $\begin{array}{l}\text { Each point on the scale is correlated } \\
\text { with a description of frailty along with } \\
\text { a visual chart to aid the tester in } \\
\text { classifying frailty }\end{array}$ & $\begin{array}{l}1 \text { (very fit) to } 9 \\
\text { (terminally ill) }\end{array}$ & $\begin{array}{l}\text { Higher scores indicate } \\
\text { higher levels of frailty }\end{array}$ & $\begin{array}{l}\text { Prevalence of frailty } 10.7 \% \text { in adults } \\
\text { aged } \geq 65 \text { years and increases to }>50 \% \\
\text { in those } \geq 80 \text { years of age [29] }\end{array}$ \\
\hline Muscular Mass & $\begin{array}{l}\text { Calf circumference } \\
\text { measurement }\end{array}$ & Assessed by tester & $\begin{array}{l}\text { Girth of mid-point calf circumference } \\
\text { measured }\end{array}$ & Width $(\mathrm{cm})$ & $\begin{array}{l}\text { Higher score indicates } \\
\text { higher levels of muscular } \\
\text { mass }\end{array}$ & $\begin{array}{l}\text { The cut-off for decreased muscle mass } \\
\text { in the elderly [32] has been identified } \\
\text { as } 34 \mathrm{~cm} \text { for men and } 33 \mathrm{~cm} \text { for } \\
\text { women }\end{array}$ \\
\hline
\end{tabular}




\subsection{Study Procedure}

The clinical lead of the Inclusion Health Service, a consultant general physician (CNC), performed an initial eligibility screen of all inpatients registered as homeless using live daily updates of the Power BI software system from November 2018 to May 2019 in St. James's Hospital. The European Typology on Homelessness and Housing Exclusion (ETHOS) definition of homeless was employed to register patients [33], which included those who were sleeping rough (those sleeping outside without cover); those living in emergency accommodation such as a hostel, night shelter, or bed and breakfast (B\&B) accommodation; those living with family and friends (where possible, this was ascertained); or in a squat.

The route to admission for participants was unplanned self-presentations to the Accident and Emergency/Emergency Department, which in cases of medical necessity, unscheduled medical admission to an inpatient ward setting for acute care followed. In the inpatient ward setting, potential participants were flagged to SK and then definitively screened against the following criteria: (i) hospital inpatient, (ii) homeless, and (iii) $>18$ years. Exclusion criteria were: (i) insufficient level of English to follow instructions required for study participation (unless translator present); (ii) cognitive impairment, delirium, agitated state, or other reasons to a degree that precluded assessment; (iii) medical or orthopaedic reasons that would preclude ability to complete test battery; and (iv) confirmed pregnancy.

Suitable patients were given a participant information leaflet and verbal information about the study. Study information was read aloud and worded appropriately to accommodate participants with literacy issues. All participants provided written informed consent prior to participation in the study, and following a process of rolling consent, the participant could quit the assessment at any point. Participants voluntarily participated in this study and no remuneration was provided. Each test was explained briefly and demonstrated to the participant. If they were willing to proceed, each test was carried out in turn.

\subsection{Statistical Analysis}

Descriptive analysis was performed with the percentage compliance with each element of the test battery reported. The reasons for non-completion were recorded. The test feasibility index or rate was assessed as a percentage. This was calculated from the number of participants who were able to participate in the test battery divided by the total number of participants who completed the test. The feasibility rates were interpreted based on pre-specified feasibility rates identified by Wouters et al. [34]: $<50 \%$, not feasible; $50-75 \%$, quite feasible; and $>75 \%$, feasible.

\section{Results}

The flow of participants through the study is shown in Figure 1. Out of 122 patients assessed for eligibility, 57 were excluded for various reasons. The most prevalent reasons were that the patient was off the ward $(n=23)$ at the time or patient refusal $(n=17)$. In some cases, potential participants who were off the ward were recruited at a later time and thus included in the study numbers $(n=65)$. The results of the test battery are reported elsewhere (paper under review).

Participant demographics are presented in Table 2. The majority of participants $(n=44,67.7 \%)$ were men and the median (IQR) age was $45(38,56)$ years with a range of 23 to 80 years. The majority of participants $(n=57,87.7 \%)$ were born in Ireland. Most participants $(n=41,64 \%)$ used hostel accommodation or were rough sleepers $(n=11$, $17 \%)$. Eleven participants $(16.9 \%)$ were re-admitted during the data collection period. More than half of the participants $(n=34,52 \%)$ admitted to consuming excess alcohol. A smaller percent $(n=23,35 \%)$ admitted to actively using heroin/intravenous drugs. Many participants suffered from pre-existing health conditions, with hepatitis $(n=27)$, liver 
disease (alcohol related) $(n=13)$, epilepsy/seizure disorders $(n=11)$, and mental health conditions $(n=17)$ being among the most common.

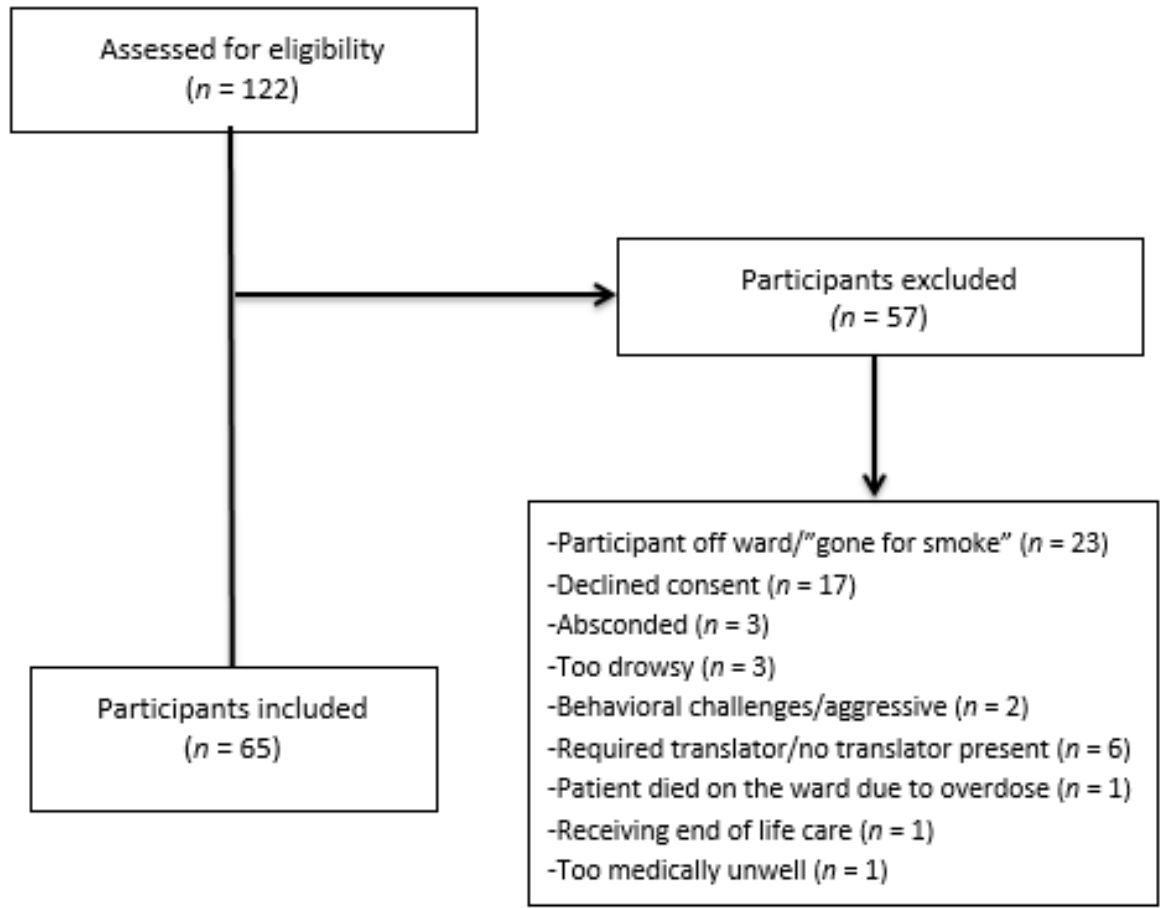

Figure 1. Flow diagram of participants through the study.

Table 2. Demographic characteristics of participants.

\begin{tabular}{ccc}
\hline Variable & N & $\%$ \\
\hline Sex & & \\
Male & 44 & 66.7 \\
Female & 21 & 32.3 \\
\hline Race/Ethnicity & & \\
White Irish & 57 & 87.7 \\
White non-Irish & 5 & 7.7 \\
African & 2 & 3.1 \\
Asian & 1 & 1.5 \\
\hline Medical conditions & & \\
Pancreatic disorders & 6 & 9.3 \\
Orthopaedic disorders & 6 & 9.3 \\
Chronic obstructive lung disease & 3 & 4.6 \\
Liver disease (alcohol related) & 13 & 20 \\
Skin disease & 5 & 7.7 \\
Ulcers & 5 & 7.7 \\
HIV & 7 & 41.8 \\
Hepatitis & 27 & 16.9 \\
Seizures & 11 & 6.1 \\
Amputee & 4 & 15.4 \\
Depression & 10 & 6.1 \\
Bipolar disorder & 4 & 4.6 \\
Schizophrenia & 3 & 3.0 \\
\hline Other mental disorder & 2 & \\
Current living arrangement & & 64.1 \\
Hostel accommodation & 41 & 16.9 \\
Rough sleeping & 11 & 7.7 \\
With family/friends & 5 & 4.6 \\
Sheltered accommodation & 3 & 4.6 \\
Hotel & 3 & 1.5 \\
Rehabilitation facility & 1 & 1.5 \\
\hline Unknown & 1 & \\
\hline
\end{tabular}

HIV: human immunodeficiency virus. 


\subsection{Compliance with Physical Performance Battery}

Participants completed some or all of the outcome measures outlined in the test battery, as shown in Table 3. The entire test battery took approximately $30 \mathrm{~min}$ to complete and was completed in the same day where possible or within the same inpatient stay.

Table 3. Numbers of participants who completed physical test battery.

\begin{tabular}{|c|c|c|c|c|c|}
\hline $\begin{array}{l}\text { Construct } \\
\text { Measured }\end{array}$ & Test & $\begin{array}{c}\text { Completed } \\
N(\%)\end{array}$ & $\begin{array}{c}\text { Women } \\
\text { Completed } \\
\quad N(\%)\end{array}$ & $\begin{array}{l}\text { Men } \\
\text { Completed } \\
N(\%)\end{array}$ & Reasons for Non-Completion \\
\hline $\begin{array}{l}\text { Lower extremity } \\
\text { function }\end{array}$ & $\begin{array}{l}\text { Short Physical } \\
\text { Performance } \\
\text { Battery (SPPB) }\end{array}$ & $42(65)$ & $9(56)$ & $33(75)$ & $\begin{array}{l}\text { Pain }(n=8), \text { not feeling able/well } \\
\text { enough }(n=5) \text {, declined }(n=5), \\
\text { non-weight bearing }(n=3), \\
\text { no appropriate footwear }(n=2)\end{array}$ \\
\hline Falls risk & $\begin{array}{l}\text { Timed up and go } \\
\text { (TUG) }\end{array}$ & $36(55.4)$ & $9(43)$ & $27(61)$ & $\begin{array}{l}\text { Pain }(n=10) \text {, declined }(n=7) \text {, no } \\
\text { appropriate footwear }(n=2) \text {, not feeling } \\
\text { able/well enough }(n=5) \text {, non-weight } \\
\text { bearing }(n=2) \text {, reasons not stated }(n=3)\end{array}$ \\
\hline $\begin{array}{l}\text { Functional } \\
\text { capacity }\end{array}$ & $\begin{array}{l}\text { Six-minute walk } \\
\text { test }(6 \mathrm{MWT})\end{array}$ & $25(38)$ & $9(43)$ & $18(41)$ & $\begin{array}{l}\text { Not feeling able/well enough }(n=13) \text {, } \\
\text { pain }(n=10) \text {, suicidal ideation }(n=2) \text {, no } \\
\text { appropriate footwear }(n=2) \text {, non-weight } \\
\text { bearing }(n=3) \text {, reasons not stated }(n=2)\end{array}$ \\
\hline $\begin{array}{l}\text { Stair-climbing } \\
\text { ability }\end{array}$ & $\begin{array}{l}\text { Stair climb test } \\
\text { (SCT) }\end{array}$ & $20(31)$ & $5(31)$ & $15(34)$ & $\begin{array}{l}\text { Unable/unsafe to do so }(n=41) \text {, feeling } \\
\text { dizzy }(n=1) \text {, pain }(n=2) \text {, afraid of stairs } \\
(n=1)\end{array}$ \\
\hline Frailty & $\begin{array}{l}\text { Clinical Frailty } \\
\text { Scale (CFS) }\end{array}$ & $63(97)$ & $21(100)$ & $42(95)$ & Lack of information to rate scale $(n=2)$ \\
\hline Grip strength & $\begin{array}{l}\text { Handgrip } \\
\text { dynamometry }\end{array}$ & $49(75)$ & $16(76)$ & $33(75)$ & $\begin{array}{l}\text { Not feeling able/well enough }(n=5), \\
\text { pain }(n=5), \text { fatigue }(n=3) \text {, suicidal } \\
\text { ideation }(n=1) \text {, broken wrist }(n=2)\end{array}$ \\
\hline Muscular mass & Calf circumference & $48(74)$ & $15(88)$ & $34(77)$ & $\begin{array}{l}\text { Not feeling able/well enough }(n=5), \\
\text { pain }(n=5) \text {, declined }(n=6) \text {, suicidal } \\
\text { ideation }(n=1)\end{array}$ \\
\hline
\end{tabular}

\subsection{Completion Rates of Performance-Based Measures}

The quite feasible [34] performance-based tests were the Short Physical Performance Battery (SPPB) (completion rate 65\%,n=42) and Timed Up and Go (TUG) (completion rate $55 \%, n=36)$. The Six-Minute Walk Test (6MWT) and Stair Climb Test (SCT) were deemed not feasible" tests [34] with completion rates of 38\% $(n=25)$ and 31\% $(n=20)$, respectively.

\subsection{Completion Rates of Tests Completed by Assessor}

The completion rate of tests performed by the assessor was higher than performancebased tests. The Clinical Frailty Scale (CFS) was a highly feasible test [34], which was completed by the majority of participants $(97 \%, n=63)$. Measurement of calf circumference was quite feasible [34] with a completion rate of $74 \%(n=48)$.

\subsection{Reasons for Non-Completion}

The specific reasons for non-completion of each test are outlined in Table 3. Collectively, the main reasons for non-completion were pain $(24.4 \%, n=40)$, not feeling well enough $(20.1 \%, n=33)$, and declined $(11 \%, n=18)$.

\section{Discussion}

This appears to be the first study to evaluate a broad physically focused test battery in hospital in-patients who were registered as homeless. In our sample, the median age was 
45 years and $67.7 \%$ were men. This is broadly comparable to other cohorts of inpatients who were homeless with an average 46 years of age and $76.1 \%$ men [35] from a U.S. study, and 48 years and $76.5 \%$ men [36] from a Spanish study. A striking finding was the inability of many participants to conduct simple standard physical tests due to pain and poor physical ability.

No physical-focused outcomes [15] have been validated and no core outcome set exists [37] specific to people who are homeless. In this study, we piloted a comprehensive experimental test battery using standard clinical and psychometrically sound tests, mainly extrapolated from the geriatric setting. We chose tests that could be easily applied in the ward-based setting, require no specialist equipment, and be easily interpreted. Despite this careful planning at the outset of this study, not all evaluation tools were feasible for use.

We found that pain was the most common reason (24.4\%) that precluded participation, highlighting the possible under-treatment of pain in this cohort. We also found that many standard geriatric tests were too challenging for this group to perform, despite a low median age of 45 years. Performance-based tests such as the SCT (31\%) and 6MWT (38\%) were not feasible [34]. Tests that were completed by the study assessor, such as the CFS (data generated for $97 \%$ of participants) and measurement of calf circumference (data generated for $74 \%$ of participants) were much more feasible [34]. There was also a higher level of feasibility [34] in low-threshold tests such as handgrip dynamometry (75\%). Due to the process of rolling consent, participants could decline to participate in a test at any time, yet declining to complete the test only applied in $11 \%$ of cases.

Positive aspects of the test battery were the duration of testing (20-30 min), which did not appear to be overly burdensome to participants. Tests were easily conducted in the clinical environment and were safe as evidenced by the lack of adverse effects, but a qualified physiotherapist conducted all tests and assessed whether participants were suitable for test participation. This indicates the need to optimise pain and refine physical evaluation tools in this cohort.

Based on the results of this study, to optimise the test battery for further use, we propose a quick standardised test battery outlined in Table 4 below that could be applied to the clinical setting and future research studies. Tests might also be useful in a primary care setting where intervention programmes could be implemented that might improve physical status. To the best of our knowledge, this is the first time that a battery of tests has been proposed for the evaluation of impairments, physical functioning, and performance among people experiencing homelessness. In recommending these tests going forward, we concede there may be a ceiling effect for a small number with high functional capacity [38,39]; therefore, close evaluation of whether tests are applicable across the spectrum of functioning [15] would be required. The next step would be to assess the feasibility, validity, reliability, and sensitivity to detect change of this test battery and establish cut-off points to identify high-risk patients. In addition, as only $38 \%$ were able to walk for $6 \mathrm{~min}$, the feasibility of other tests should be investigated such as the $1 \mathrm{~min}$ sit-to-stand test, which has been used in Chronic Obstructive Pulmonary Disease (COPD) populations [40], and gait speed over a $6 \mathrm{~m}$ course [41]. As pain was the main reason for not participating in tests, we recommend that pain is screened and optimised before the conduction of any physical tests in clinical or research settings. Although the proposed test battery would not be onerous in terms of time, we recommend that if testing could not be completed in its entirety in one session due to reasons such as fatigue or difficulties maintaining focus on physical tasks, that it could be conducted over a number of sessions within a meaningful time period (e.g., single hospital admission). 
Table 4. Proposed test battery to evaluate physical functioning limitations in people who are homeless.

\begin{tabular}{ccc}
\hline Test & Construct Measured & Reason for Choice/Caution \\
\hline CFS & Frailty & High feasibility, completed by tester \\
\hline Handgrip dynamometry & Strength & $\begin{array}{c}\text { Low-threshold test to maximise } \\
\text { participation }\end{array}$ \\
\hline $\begin{array}{c}\text { Calf and upper limb } \\
\text { circumference }\end{array}$ & Muscle mass & $\begin{array}{c}\text { To allow for lower limb swelling, } \\
\text { also measure upper limb }\end{array}$ \\
\hline SPPB & $\begin{array}{c}\text { Physical performance/ } \\
\text { falls risk }\end{array}$ & $\begin{array}{c}\text { Likely ceiling effect for a small } \\
\text { number of high-level performers }\end{array}$ \\
\hline
\end{tabular}

Contextual factors may also be important to consider in the interpretation of this study. Firstly, homeless populations in the U.S. include a high proportion of veterans and ethnic minorities, while the study cohort in Dublin, Ireland, reflecting previous work, includes predominantly white Irish participants and very few war veterans [12]. For instance, in our study $>90 \%$ were white, which is higher than the U.S. study of hospitalised homeless, which included $62 \%$ white people [35]. A second major difference is that publiclyfunded free primary and secondary healthcare is available to those falling into the lowest one-third income bracket in Ireland, so insurance status is not a factor limiting inpatient hospital care. Thirdly, in Dublin, homelessness is closely linked to drug use: up to 70\% of homeless individuals report having used illegal drugs, many with poly drug use, and $>50 \%$ report injecting drugs [42]. Approximately $70 \%$ of homeless individuals in Dublin consume alcohol at dangerous levels [42]. This reflects that diseases related to alcohol and drug use (abscesses, hepatic failure and haematemesis) as well as seizures are also more common among homeless inpatients in Ireland, which may result from the increased rate of traumatic brain injury and substance use in this population [12]. It is not known whether this profile limits the interpretation of results in other settings.

Other limitations to consider were that participants experienced a burden of physical and medical conditions that may have interacted with testing, which is an inherent limitation of evaluating a physical test battery in an acute hospital population. The exact reason for unscheduled medical admission was not recorded for the purposes of the present study. A previous detailed analysis of homeless inpatients $(n=459)$ within our centre [12] revealed that $94.9 \%$ of unscheduled medical admissions were due to physical health needs including pneumonia/bronchitis $(11.8 \%)$, seizures $(8.5 \%)$, syncope and collapse $(5.7 \%)$, acute exacerbation of COPD/asthma (5.3\%), abscess (5.0\%), cellulitis (4.8\%), venous thromboembolism $(3.5 \%)$, haematemesis $(3.27 \%)$, hepatic failure $(2.18 \%)$, and alcohol withdrawal $(2.18 \%)$. It is likely that a similar pattern pertained to the present study. Acute or chronic presentation of one or more of these conditions or acute trauma may have influenced mobility levels at the time of testing and therefore the ability to participate in the test battery, the extent to which is difficult to elucidate. A further limitation was that this study was subject to selection bias, as all participants were recruited as hospital inpatients. Data were collected from one urban hospital setting, but as deficits in physical functioning ability are prevalent [15] among a range of homeless settings, results may be cautiously applicable to homeless shelters and hostels, but this requires further evaluation. We concede that comparing other non-homeless hospitalised patients matched by factors such as age, sex, and co-morbidities would provide a useful objective comparison, but this was beyond the scope of the present study. This should be a focus for a follow-up study. Finally, we excluded participants with severe impairment who were unable to complete the majority of the test battery due to orthopaedic or medical reasons. Therefore, this study may unwittingly be a snapshot of participation levels in those with less-severe physical ability.

The strengths of this study were the application of psychometrically sound measures to evaluate constructs of impairments, physical functioning and performance. A qualified physiotherapist familiar with the testing battery performed all tests and followed stan- 
dardised methodology. In addition, a reasonable sample size to gather perspectives on the feasibility of these measures was generated in this study.

\section{Conclusions}

To assess physical ability, it is necessary to use appropriate tools that are contextspecific to the population under evaluation. We found the most feasible tests were the CFS, handgrip dynamometry, and calf circumference measurement. The 6MWT and SCT were not feasible tests for use in this cohort. Based on results of this study, we propose a test battery that may be feasible for use in this population. This requires further evaluation, but may be useful for research and clinical studies to more closely investigate physical functioning limitations in people who are homeless.

Author Contributions: Original conception and design of study: C.N.C., N.M., J.D., and J.B. Participant recruitment and screening: C.N.C. Participant testing, data collection and analysis of results: S.K. and J.B. Study Supervision: C.N.C., J.B., and N.M., Drafting of paper: J.B. and C.N.C. Editing of paper: J.B., C.N.C., N.M., J.D., and S.K. All authors have read and agreed to the published version of the manuscript.

Funding: This study did not receive grants from any funding agencies in the public commercial, or not-for-profit sectors.

Institutional Review Board Statement: The study was conducted according to the guidelines of the Declaration of Helsinki, and approved by the Tallaght University Hospital/St. James's Hospital Research Ethics Committee (Reference: 2018-10 List 35(3)) which was granted on 30 October 2018.

Informed Consent Statement: Informed consent was obtained from all subjects involved in the study.

Data Availability Statement: Not applicable.

Conflicts of Interest: The authors have no conflict of interest to declare.

\section{References}

1. National Health Care for the Homeless Council. Official Definition of Homelessness. Available online: https://www.nhchc.org/ faq/official-definition-homelessness / (accessed on 23 March 2020).

2. Shelter. Far from Alone: Homelessness in Britain in 2017. Available online: https://england.shelter.org.uk/_data/assets/pdf_ file/0017/1440053/8112017_Far (accessed on 19 May 2019).

3. National Alliance to End Homelessness. State of Homelessness. Available online: https://endhomelessness.org/homelessnessin-america/homelessness-statistics/state-of-homelessness-report/ (accessed on 1 August 2019).

4. Gaetz, S.D.; Richter, T.E.; Redman, M. The State of Homelessness in Canada. 2016. Available online: https://homelesshub.ca/ sites/default/files/SOHC16_final_200ct2016.pdf (accessed on 23 March 2020).

5. Focus Ireland. Available online: https://www.focusireland.ie/resource-hub/about-homelessness/ (accessed on 17 September 2020).

6. Hibbs, J.R.; Benner, L.; Klugman, L.; Spencer, R.; Macchia, I.; Mellinger, A.; Fife, D.K. Mortality in a cohort of homeless adults in Philadelphia. N. Engl. J. Med. 1994, 331, 304-309. [CrossRef] [PubMed]

7. Office for National Statistics. Deaths of Homeless People in England and Wales. Available online: https://www.ons.gov.uk/ peoplepopulationandcommunity/birthsdeathsandmarriages/deaths/bulletins/deathsofhomelesspeopleinenglandandwales / 2018 (accessed on 30 March 2020).

8. Fazel, S.; Geddes, J.R.; Kushel, M. The health of homeless people in high-income countries: Descriptive epidemiology, health consequences, and clinical and policy recommendations. Lancet 2014, 384, 1529-1540. [CrossRef]

9. Arnold, E.M.; Strenth, C.R.; Hedrick, L.P.; Paterson, R.C.; Curiel, J.; Joseph, A.E.; Brown, T.W.; Kimball, J.N. Medical Comorbidities and Medication Use Among Homeless Adults Seeking Mental Health Treatment. Community Ment. Health J. 2020, 56, 885-893. [CrossRef] [PubMed]

10. Lewer, D.; Aldridge, R.W.; Menezes, D.; Sawyer, C.; Zaninotto, P.; Dedicoat, M.; Ahmed, I.; Luchenski, S.; Hayward, A.; Story, A. Health-related quality of life and prevalence of six chronic diseases in homeless and housed people: A cross-sectional study in London and Birmingham, England. BMJ Open 2019, 9, e025192. [CrossRef] [PubMed]

11. Bowen, M.; Marwick, S.; Marshall, T.; Saunders, K.; Burwood, S.; Yahyouche, A.; Stewart, D.; Paudyal, V. Multimorbidity and emergency department visits by a homeless population: A database study in specialist general practice. Br. J. Gen. Pract. J. R. Coll. Gen. Pract. 2019, 69, e515-e525. [CrossRef] [PubMed] 
12. Ni Cheallaigh, C.; Cullivan, S.; Sears, J.; Lawlee, A.M.; Browne, J.; Kieran, J.; Segurado, R.; O'Carroll, A.; O’Reilly, F.; Creagh, D.; et al. Usage of unscheduled hospital care by homeless individuals in Dublin, Ireland: A cross-sectional study. BMJ Open 2017, 7, e016420. [CrossRef] [PubMed]

13. Doran, K.M.; Ragins, K.T.; Iacomacci, A.L.; Cunningham, A.; Jubanyik, K.J.; Jenq, G.Y. The revolving hospital door: Hospital readmissions among patients who are homeless. Med. Care 2013, 51,767-773. [CrossRef]

14. Kushel, M.B.; Perry, S.; Bangsberg, D.; Clark, R.; Moss, A.R. Emergency department use among the homeless and marginally housed: Results from a community-based study. Am. J. Public Health 2002, 92, 778-784. [CrossRef] [PubMed]

15. Kiernan, S.; Mockler, D.; Cheallaigh, C.N.; Broderick, J. Physical Functioning and Physical Activity of People Experiencing Homelessness: A Scoping review. HRB Open Res. 2020, 3, 14. [CrossRef]

16. Brown, R.T.; Hemati, K.; Riley, E.D.; Lee, C.T.; Ponath, C.; Tieu, L.; Guzman, D.; Kushel, M.B. Geriatric Conditions in a Population-Based Sample of Older Homeless Adults. Gerontologist 2017, 57, 757-766. [CrossRef]

17. Penninx, B.W.; Ferrucci, L.; Leveille, S.G.; Rantanen, T.; Pahor, M.; Guralnik, J.M. Lower extremity performance in nondisabled older persons as a predictor of subsequent hospitalization. J. Gerontol. Ser. A Biol. Sci. Med Sci. 2000, 55, M691-M697. [CrossRef] [PubMed]

18. Guralnik, J.M.; Simonsick, E.M.; Ferrucci, L.; Glynn, R.J.; Berkman, L.F.; Blazer, D.G.; Scherr, P.A.; Wallace, R.B. A short physical performance battery assessing lower extremity function: Association with self-reported disability and prediction of mortality and nursing home admission. J. Gerontol. 1994, 49, M85-M94. [CrossRef] [PubMed]

19. Pavasini, R.; Guralnik, J.; Brown, J.C.; di Bari, M.; Cesari, M.; Landi, F.; Vaes, B.; Legrand, D.; Verghese, J.; Wang, C.; et al. Short Physical Performance Battery and all-cause mortality: Systematic review and meta-analysis. BMC Med. 2016, 14, 215. [CrossRef] [PubMed]

20. Steffen, T.M.; Hacker, T.A.; Mollinger, L. Age- and gender-related test performance in community-dwelling elderly people: Six-Minute Walk Test, Berg Balance Scale, Timed Up \& Go Test, and gait speeds. Phys. Ther. 2002, 82, 128-137. [PubMed]

21. Barry, E.; Galvin, R.; Keogh, C.; Horgan, F.; Fahey, T. Is the Timed Up and Go test a useful predictor of risk of falls in community dwelling older adults: A systematic review and meta-analysis. BMC Geriatr. 2014, 14, 14. [CrossRef]

22. Podsiadlo, D.; Richardson, S. The timed "Up \& Go": A test of basic functional mobility for frail elderly persons. J. Am. Geriatr. Soc. 1991, 39, 142-148.

23. Shumway-Cook, A.; Brauer, S.; Woollacott, M. Predicting the probability for falls in community-dwelling older adults using the Timed Up \& Go Test. Phys. Ther. 2000, 80, 896-903.

24. ATS BOARDOF. ATS statement: Guidelines for the six-minute walk test. Am. J. Respir. Crit. Care Med. 2002, 166, 111-117. [CrossRef]

25. Camarri, B.; Eastwood, P.R.; Cecins, N.M.; Thompson, P.J.; Jenkins, S. Six minute walk distance in healthy subjects aged 55-75 years. Respir. Med. 2006, 100, 658-665. [CrossRef]

26. Bennell, K.; Dobson, F.; Hinman, R. Measures of physical performance assessments: Self-Paced Walk Test (SPWT), Stair Climb Test (SCT), Six-Minute Walk Test (6MWT), Chair Stand Test (CST), Timed Up \& Go (TUG), Sock Test, Lift and Carry Test (LCT), and Car Task. Arthritis Care Res. 2011, 63 (Suppl. S11), S350-S370.

27. Dobson, F.; Hinman, R.S.; Roos, E.M.; Abbott, J.H.; Stratford, P.; Davis, A.M.; Buchbinder, R.; Snyder-Mackler, L.; Henrotin, Y.; Thumboo, J.; et al. OARSI recommended performance-based tests to assess physical function in people diagnosed with hip or knee osteoarthritis. Osteoarthr. Cartil. 2013, 21, 1042-1052. [CrossRef] [PubMed]

28. Rockwood, K.; Song, X.; MacKnight, C.; Bergman, H.; Hogan, D.B.; McDowell, I.; Mitnitski, A. A global clinical measure of fitness and frailty in elderly people. CMAJ 2005, 173, 489-495. [CrossRef] [PubMed]

29. Collard, R.M.; Boter, H.; Schoevers, R.A.; Oude Voshaar, R.C. Prevalence of frailty in community-dwelling older persons: A systematic review. J. Am. Geriatr. Soc. 2012, 60, 1487-1492. [CrossRef]

30. Leong, D.P.; Teo, K.K.; Rangarajan, S.; Lopez-Jaramillo, P.; Avezum, A., Jr.; Orlandini, A.; Seron, P.; Ahmed, S.H.; Rosengren, A.; Kelishadi, R.; et al. Prognostic value of grip strength: Findings from the Prospective Urban Rural Epidemiology (PURE) study. Lancet 2015, 386, 266-273. [CrossRef]

31. Steiber, N. Strong or Weak Handgrip? Normative Reference Values for the German Population across the Life Course Stratified by Sex, Age, and Body Height. PLoS ONE 2016, 11, e0163917. [CrossRef]

32. Pagotto, V.; Santos, K.F.D.; Malaquias, S.G.; Bachion, M.M.; Silveira, E.A. Calf circumference: Clinical validation for evaluation of muscle mass in the elderly. Rev. Bras. Enferm. 2018, 71, 322-328. [CrossRef]

33. FEANTSA. "On the Way Home?" FEANTSA Monitoring Report on Homelessness and Homelessness Policies in Europe; FEANTSA: Brussels, Belgium, 2012.

34. Wouters, M.; van der Zanden, A.M.; Evenhuis, H.M.; Hilgenkamp, T.I.M. Feasibility and Reliability of Tests Measuring HealthRelated Physical Fitness in Children with Moderate to Severe Levels of Intellectual Disability. Am. J. Intellect. Dev. Disabil. 2017, 122, 422-438. [CrossRef]

35. Wadhera, R.K.; Choi, E.; Shen, C.; Yeh, R.W.; Joynt Maddox, K.E. Trends, Causes, and Outcomes of Hospitalizations for Homeless Individuals: A Retrospective Cohort Study. Med. Care 2019, 57, 21-27. [CrossRef] [PubMed]

36. Tornero Patricio, S.; Fernández Ajuria, A.; Charris Castro, L. Characteristics of Hospitalizations of Homeless Persons in Seville, Spain. Rev. Esp. Salud Publica 2016, 90, E12. 
37. Kirkham, J.J.; Gorst, S.; Altman, D.G.; Blazeby, J.M.; Clarke, M.; Devane, D.; Gargon, E.; Moher, D.; Schmitt, J.; Tugwell, P.; et al. Core Outcome Set-STAndards for Reporting: The COS-STAR Statement. PLoS Med. 2016, 13, e1002148. [CrossRef]

38. Randers, M.B.; Nybo, L.; Petersen, J.; Nielsen, J.J.; Christiansen, L.; Bendiksen, M.; Brito, J.; Bangsbo, J.; Krustrup, P. Activity profile and physiological response to football training for untrained males and females, elderly and youngsters: Influence of the number of players. Scand. J. Med. Sci. Sports 2010, 20 (Suppl. S1), 14-23. [CrossRef] [PubMed]

39. Randers, M.B.; Petersen, J.; Andersen, L.J.; Krustrup, B.R.; Hornstrup, T.; Nielsen, J.J.; Nordentoft, M.; Krustrup, P. Short-term street soccer improves fitness and cardiovascular health status of homeless men. Eur. J. Appl. Physiol. 2012, 112, 2097-2106. [CrossRef] [PubMed]

40. Van Gestel, A.J.; Clarenbach, C.F.; Stöwhas, A.C.; Rossi, V.A.; Sievi, N.A.; Camen, G.; Russi, E.W.; Kohler, M. Predicting daily physical activity in patients with chronic obstructive pulmonary disease. PLoS ONE 2012, 7, e48081. [CrossRef] [PubMed]

41. Cesari, M.; Kritchevsky, S.B.; Newman, A.B.; Simonsick, E.M.; Harris, T.B.; Penninx, B.W.; Brach, J.S.; Tylavsky, F.A.; Satterfield, S.; Bauer, D.C.; et al. Added value of physical performance measures in predicting adverse health-related events: Results from the Health, Aging and Body Composition Study. J. Am. Geriatr. Soc. 2009, 57, 251-259. [CrossRef] [PubMed]

42. O'Reilly, F.; Barror, S.; O'Carroll, A. Homelessness: An Unhealthy State: Partnership for Health Equality 2015. Available online: https://www.drugsandalcohol.ie/24541/ (accessed on 17 September 2020). 